\title{
Genetic variation in wood density and correlations with tree growth in Prosopis africana from Burkina Faso and Niger
}

\author{
Carmen Sotelo Montes*, John C.WeBer \\ World Agroforestry Centre (ICRAF), West and Central Africa Regional Office, B.P. E5118, Bamako, Mali
}

(Received 30 July 2008; revised version 10 November 2008; accepted 25 March 2009)

Keywords:

Sahel /

adaptation /

conservation /

tree improvement

\begin{abstract}
- Variation in wood basic density and its correlation with tree growth were investigated at 13 years in a provenance/progeny test of Prosopis africana in Niger. The test included progeny from 256 trees sampled from 24 provenances in the Sahelian ecozone of Burkina Faso and Niger.

- Variation in wood density was significant due to provenances and families within provenances. Individual tree heritability was higher for wood density than for growth traits. Provenance means for wood density increased from the more humid to the drier parts of the sample region. Phenotypic correlations indicated that larger trees tended to have denser wood.

- Clines suggest that natural populations of $P$. africana from the drier parts of the sample region have the genetic capacity to produce denser wood, compared with populations from the more humid parts of the region. Correlations and heritability estimates suggest that selection of faster-growing trees may produce a small gain in wood volume but little (if any) gain in density in the subsequent generation. Multi-location provenance/tests are needed to confirm this tentative conclusion.
\end{abstract}

Résumé - Variation génétique de la densité du bois et corrélations avec la croissance de l'arbre chez Prosopis africana provenant du Burkina Faso et du Niger.

- La variation de la densité du bois et sa corrélation avec la croissance de l'arbre ont été étudiées à l'âge de 13 ans dans un essai de provenances/descendances de Prosopis africana au Niger. L'essai a inclus les descendances de 256 arbres mères provenant de 24 provenances de l'écozone sahélienne du Burkina Faso et du Niger.

- La variation de la densité du bois a été significative en relation avec les provenances et les familles à l'intérieur des provenances. L'héritabilité a été plus élevée pour la densité que pour les caractères de croissance de l'arbre. La densité moyenne des provenances a augmenté des sites les plus humides aux sites les plus secs de la région échantillonnée. Les corrélations phénotypiques ont montré que les plus grands arbres ont eu tendance à avoir le bois le plus dense.

- Les clines suggèrent que les populations naturelles de $P$. africana des sites les plus secs de la région échantillonnée ont la capacité génétique de produire du bois plus dense que les populations des sites les plus humides de la région. Les corrélations et les héritabilités estimées suggèrent que la sélection d'arbres à croissance rapide peut produire un faible gain en volume de bois et très peu de gain en densité du bois dans la génération suivante. Des essais de provenance/descendance dans plusieurs sites sont nécessaires pour confirmer cette conclusion provisoire.

\section{INTRODUCTION}

In order to enhance sustainable management and conservation of timber-tree species, tree improvement programs must have information about the distribution of genetic variation in commercially important traits among and within natural populations, the correlation between tree growth and wood density,

*Corresponding author: c.sotelo@cgiar.org and the heritability of growth traits and wood density. Understanding the distribution of genetic variation is necessary in order to develop the most effective strategy for selecting provenances and families within provenances. Wood density is a key trait because it is often correlated with other commercially important, wood-quality traits (Panshin and de Zeeuw, 1980). In many species with diffuse-porous wood, there is no significant correlation between growth rate and wood density, suggesting that faster-growing trees could be selected without 
affecting wood quality (Zobel and Jett, 1995); but the correlation may be positive in some species and negative in others, and it may also vary among provenances within a species (e.g., Sotelo Montes et al., 2006; Weber and Sotelo Montes, 2008). In addition, wood density and other wood properties tend to be under stronger genetic control than growth traits (Zobel and Jett, 1995), so selection based on wood density may be more effective than selection based on tree growth rate.

Prosopis africana (Guill., Perrott. and Rich.) Taub. (Leguminosae, sub-family Mimosoideae) is very important for farming and pastoralist communities in the West African Sahel. The species extends from the relatively humid Sudanian and Guinean ecozones in the south to the drier Sahelian ecozone in the north, but it is disappearing in many regions due to overexploitation and the increasingly hotter and drier climate in the region (Weber et al., 2008). The wood is diffuse porous, moderately dense (Nygård and Elving, 2000) and used for construction poles, planks, mortars, pestles, artisan products, handles for farm implements, firewood and charcoal (Pasiecznik et al., 2001). Trees produce a deep taproot, grow slowly and can be coppiced. The breeding system is assumed to be primarily out-crossing (e.g., Bessega et al., 2000), and seeds are dispersed by browsing animals (Tybirk, 1991) and humans (A. Bationo, personnel communication).

The first provenance/progeny test of $P$. africana included provenances and families from the Sahelian ecozone of Burkina Faso and Niger, and was established at a relatively dry site in Niger. Results from the test at 11 years indicate that tree growth and survival vary significantly due to provenances, and that provenance growth and survival increase from the more humid to the drier parts of the sample region (Weber et al., 2008). The cline with rainfall gradients support the theoretical expectation that provenances from the drier parts of the sample region are better adapted to drought. In this paper, additional results are presented from the test at 13 years. The main objectives are to (a) determine if wood density varies significantly due to provenances and families within provenances, (b) assess whether the distribution of genetic variation among and within provenances is similar for wood density and tree growth traits, (c) compare the heritability of wood density and tree growth traits, (d) determine if wood density increases from the more humid to the drier parts of the sample region, and (e) estimate phenotypic and genetic correlations between wood density and tree growth traits. Results are compared with those of other tropical hardwood species, and some practical implications are discussed.

\section{MATERIALS AND METHODS}

\subsection{Sample region, experimental design and management of the provenance/progeny test}

The sample region extends from central Burkina Faso to central Niger, covering an area approximately $1200 \mathrm{~km}$ from west to east, and 50-200 km from south to north (Fig. A available online at www.afs-journal.org). Mean annual rainfall decreases from west to east $(\sim 750-350 \mathrm{~mm})$ and from south to north $(\sim 750-650 \mathrm{~mm}$ in the west, $\sim 450-350 \mathrm{~mm}$ in the east); mean annual temperature is approximately $28-29{ }^{\circ} \mathrm{C}$; and the soils are generally sandy and infertile. Seeds were collected from mother trees in 28 natural stands in 1993, and the latitude, longitude and elevation were recorded for each mother tree. The provenance/progeny test was established in 1994 at the ICRISAT Sahelian Centre, located near Niamey, Niger. Mean annual rainfall and temperature are $539 \mathrm{~mm}$ and $29{ }^{\circ} \mathrm{C}$, respectively, at the test site. The experimental design was a randomized complete block, with eight blocks (replications) and 275 families. Each replication included one tree per family. Additional details about the sample region, seed collection, nursery production, experimental design and management of the provenance/progeny test are given elsewhere (Weber et al., 2008).

\subsection{Data collection and statistical analyses}

Tree growth and basic density of the wood were evaluated 13 years after trial establishment. Growth traits included tree height (Height), stem diameter over bark (DBHOB) and under bark (DBHUB) measured at breast height $(1.3 \mathrm{~m}$ above ground level). One disk $(2 \mathrm{~cm}$ thick) was sampled from the stem at breast height, the bark was removed, and basic density (BD) was determined using the waterdisplacement method (ASTM, 1997).

Data from 24 provenances were analyzed (Tab. I): four provenances were excluded because they had fewer than 20 living trees. The SAS ${ }^{\circledR}$ statistical package (SAS Institute Inc., 2004) was used for all analyses, and the significance level was $\alpha \leq 0.05$ for all tests.

Data for each tree were adjusted for the number of living trees (0-8) immediately surrounding the tree. The number of living trees was included as a covariate in the analysis of variance (ANOVA) model described below, and the covariate parameter estimate was used to adjust the data.

ANOVA (MIXED procedure, restricted maximum likelihood method) was used to determine if wood density varied significantly due to provenances and families within provenances. The ANOVA model was: $Y_{i j k l}=\mu+\alpha_{i}+\beta_{j}+\gamma_{k(j)}+\alpha \beta_{i j}+\varepsilon_{i j k l}$, where $Y_{i j k l}=$ tree $_{l}$ in treatment combination ${ }_{i j k}, \mu=$ the grand mean, $\alpha_{i}=$ replication $_{i}, \beta_{j}=$ provenance $_{j}, \gamma_{k(j)}=$ family $_{k}$ nested within provenance ${ }_{j}, \alpha \beta_{i j}=$ interaction between replication ${ }_{i}$ and provenance ${ }_{j}$, and $\varepsilon_{i j k l}=$ residual error. All factors were considered random, and $Z$-tests were used to determine if variance components were significantly greater than zero. Each variance component was expressed as a percentage of the total variance ( $\mathrm{VC} \%$ ), defined as the sum of all variance components in the model. A minimum sample size of 40 is recommended to obtain accurate estimates of variance components (N. Mandel, personal communication): the number was adequate for families but lower than recommended for provenances.

Growth traits were analyzed using the same ANOVA model described above. VC\% was used to assess whether the relative magnitude of variation among and within populations was similar for wood density and growth traits.

Individual tree heritability $\left(h_{i}^{2}\right)$ of wood density and growth traits was estimated only if there was significant variation due to families. We assumed partial inbreeding and estimated additive genetic variance as $3 \sigma_{f}^{2}$, as others have done (e.g., Sotelo Montes et al., 2006). Standard errors were calculated using the formula provided by Becker (1984). If the standard error was equal to or greater than $h_{i}^{2}$, then $h_{i}^{2}$ was not considered to be significantly greater than zero.

Clinal variation in mean wood density of the provenances was investigated using multiple linear regression (REG procedure). The 
Table I. Geographic location of 24 Prosopis africana provenances from Niger and Burkina Faso analyzed in a provenance/progeny test in Niger. Provenances are ordered by longitude, from west to east ${ }^{\mathrm{a}}$.

\begin{tabular}{|c|c|c|c|c|c|}
\hline Code & Provenance & Latitude & Longitude & Elevation (m) & Mother trees \\
\hline 28 & Yiimigu & $12^{\circ} 53^{\prime} 38^{\prime \prime} \mathrm{N}$ & $1^{\circ} 17^{\prime} 32^{\prime \prime} \mathrm{W}$ & 316 & 11 \\
\hline 26 & Rapadama & $12^{\circ} 19^{\prime} 29^{\prime \prime} \mathrm{N}$ & $0^{\circ} 57^{\prime} 13^{\prime \prime} \mathrm{W}$ & 275 & 13 \\
\hline 27 & Boukouin & $12^{\circ} 59^{\prime} 31^{\prime \prime} \mathrm{N}$ & $0^{\circ} 14^{\prime} 6^{\prime \prime} \mathrm{E}$ & 268 & 11 \\
\hline 24 & Natoumpe & $12^{\circ} 12^{\prime} 55^{\prime \prime} \mathrm{N}$ & $1^{\circ} 15^{\prime} 23^{\prime \prime} \mathrm{E}$ & 217 & 8 \\
\hline 9 & Torodi & $13^{\circ} 1^{\prime} 5^{\prime \prime} \mathrm{N}$ & $1^{\circ} 45^{\prime} 34^{\prime \prime} \mathrm{E}$ & 269 & 9 \\
\hline 6 & Kone-Beri & $13^{\circ} 45^{\prime} 38^{\prime \prime} \mathrm{N}$ & $2^{\circ} 4^{\prime} 31^{\prime \prime} \mathrm{E}$ & 223 & 12 \\
\hline 10 & Gueme & $12^{\circ} 40^{\prime} 12^{\prime \prime} \mathrm{N}$ & $2^{\circ} 24^{\prime} 39^{\prime \prime} \mathrm{E}$ & 232 & 11 \\
\hline 1 & Ngonga & $13^{\circ} 11^{\prime} 20^{\prime \prime} \mathrm{N}$ & $2^{\circ} 48^{\prime} 15^{\prime \prime} \mathrm{E}$ & 228 & 5 \\
\hline 2 & Beylande & $12^{\circ} 45^{\prime} 8^{\prime \prime} \mathrm{N}$ & $2^{\circ} 49^{\prime} 56^{\prime \prime} \mathrm{E}$ & 217 & 12 \\
\hline 7 & Baleyara-Winditan & $13^{\circ} 45^{\prime} 16^{\prime \prime} \mathrm{N}$ & $2^{\circ} 52^{\prime} 0^{\prime \prime} \mathrm{E}$ & 228 & 8 \\
\hline 5 & Diambabade & $13^{\circ} 16^{\prime} 25^{\prime \prime} \mathrm{N}$ & $3^{\circ} 12^{\prime} 55^{\prime \prime} \mathrm{E}$ & 253 & 12 \\
\hline 4 & Farey & $12^{\circ} 35^{\prime} 31^{\prime \prime} \mathrm{N}$ & $3^{\circ} 17^{\prime} 4^{\prime \prime} \mathrm{E}$ & 238 & 12 \\
\hline 3 & $\mathrm{Sia}$ & $12^{\circ} 00^{\prime} 25^{\prime \prime} \mathrm{N}$ & $3^{\circ} 18^{\prime} 54^{\prime \prime} \mathrm{E}$ & 231 & 12 \\
\hline 11 & Tounga-Bouremi & $13^{\circ} 7^{\prime} 39^{\prime \prime} \mathrm{N}$ & $3^{\circ} 42^{\prime} 13^{\prime \prime} \mathrm{E}$ & 260 & 12 \\
\hline 12 & Matankari & $13^{\circ} 49^{\prime} 33^{\prime \prime} \mathrm{N}$ & $4^{\circ} 0^{\prime} 18^{\prime \prime} \mathrm{E}$ & 224 & 15 \\
\hline 13 & Dankassari & $13^{\circ} 44^{\prime} 44^{\prime \prime} \mathrm{N}$ & $4^{\circ} 23^{\prime} 24^{\prime \prime} \mathrm{E}$ & 291 & 6 \\
\hline 15 & Bodossa & $13^{\circ} 57^{\prime} 42^{\prime \prime} \mathrm{N}$ & $5^{\circ} 11^{\prime} 32^{\prime \prime} \mathrm{E}$ & 278 & 6 \\
\hline 17 & Guidan-Rou & $13^{\circ} 37^{\prime} 36^{\prime \prime} \mathrm{N}$ & $6^{\circ} 42^{\prime} 33^{\prime \prime} \mathrm{E}$ & 293 & 7 \\
\hline 18 & Maradi & $13^{\circ} 27^{\prime} 9^{\prime \prime} \mathrm{N}$ & $7^{\circ} 2^{\prime} 51^{\prime \prime} \mathrm{E}$ & 304 & 11 \\
\hline 19 & Aguié & $13^{\circ} 32^{\prime} 28^{\prime \prime} \mathrm{N}$ & $7^{\circ} 48^{\prime} 15^{\prime \prime} \mathrm{E}$ & 376 & 14 \\
\hline 20 & Kongome & $13^{\circ} 41^{\prime} 32^{\prime \prime} \mathrm{N}$ & $8^{\circ} 16^{\prime} 48^{\prime \prime} \mathrm{E}$ & 439 & 13 \\
\hline 21 & Matamaye & $13^{\circ} 25^{\prime} 40^{\prime \prime} \mathrm{N}$ & $8^{\circ} 30^{\prime} 1^{\prime \prime} \mathrm{E}$ & 462 & 12 \\
\hline 22 & Magaria & $12^{\circ} 58^{\prime} 53^{\prime \prime} \mathrm{N}$ & $8^{\circ} 54^{\prime} 10^{\prime \prime} \mathrm{E}$ & 396 & 12 \\
\hline 23 & Kassari & $13^{\circ} 32^{\prime} 37^{\prime \prime} \mathrm{N}$ & $9^{\circ} 10^{\prime} 54^{\prime \prime} \mathrm{E}$ & 404 & 12 \\
\hline
\end{tabular}

${ }^{\text {a }}$ Provenances 1-23 from Niger and 24-28 from Burkina Faso. Mean latitude, longitude and elevation of mother trees collected in each provenance.

model was selected using the backward technique: provenance latitude, longitude and elevation were entered as independent variables in a preliminary model, and this was reduced by eliminating variables that were not significant. Mean latitude, longitude and elevation were computed for each provenance using the location of the mother trees. Accurate rainfall data were not available for most provenances, so regressions could not be carried out directly with rainfall data.

Phenotypic correlations were calculated between wood density and growth traits using data from all trees and separately for trees in each provenance (Pearson $r$, CORR procedure). Genetic correlations were estimated only if there was significant variation due to families for both traits: values were standardized in order to eliminate any effect due to different measurement scales, and approximate standard errors were calculated using the formula provided by Falconer and Mackay (1996). Genetic correlations were not estimated within provenances due to the small sample sizes.

\section{RESULTS}

There were relatively large differences in wood density among provenances and especially among families of $P$. africana. Mean density was $606.3 \mathrm{~kg} / \mathrm{m}^{3}$, and the range in means was $54.5 \mathrm{~kg} / \mathrm{m}^{3}$ among provenances and $178.3 \mathrm{~kg} / \mathrm{m}^{3}$ among families (Tab. A gives provenance means, available online at afsjournal.org).

There was significant variation in wood density due to both provenances and families within provenances (Tab. II). The distribution of variation differed between wood density and the growth traits: provenances accounted for relatively more variation than families in growth, whereas families accounted for relatively more variation than provenances in density.

Wood density had a higher $h_{i}^{2}(0.34$, standard error $=0.15)$ than tree height $(0.22$, standard error $=0.14)$. The $h_{i}^{2}$ for DBHOB $(0.14$, standard error $=0.14)$ was not significantly greater than zero, based on the large standard error. Estimates were based on 256 families $(N=1062,1063$ and 1078 trees for density, DBHOB and height, respectively).

Linear regression indicated that mean wood density of provenances increased with latitude, i.e. from the more humid to the drier parts of the sample region (regression equation: $440.1636+12.5753 \times$ latitude; model $R^{2}=0.316 ; P$ and standard error of regression coefficient $=0.004$ and 3.9461, respectively; $N=24$ ).

Phenotypic correlations indicated that larger trees tended to have denser wood, but genetic correlations were not significantly greater than zero (Tab. III). The magnitude of the phenotypic correlations between wood density and growth traits varied among provenances (not tabled). For example, the correlation between density and height ranged from 0.226 $(N=43, P>0.05)$ to $0.575(N=36, P<0.001)$.

\section{DISCUSSION}

To our knowledge, this is the first published report of genetic variation in wood density and its correlation with tree growth in a native African hardwood species. This study 
Table II. Analysis of variance of wood density and growth of Prosopis africana trees evaluated at 13 years in a provenance/progeny test in Niger ${ }^{\mathrm{a}, \mathrm{b}, \mathrm{c}, \mathrm{d}}$.

\begin{tabular}{|c|c|c|c|c|c|c|c|c|}
\hline \multirow[t]{2}{*}{ Source of variation } & \multicolumn{2}{|c|}{$\mathrm{BD}(N=1062)$} & \multicolumn{2}{|c|}{ Height $(N=1078)$} & \multicolumn{2}{|c|}{ DBHOB $(N=1063)$} & \multicolumn{2}{|c|}{ DBHUB $(N=1063)$} \\
\hline & $P Z$ & $\mathrm{VC} \%$ & $P Z$ & $\mathrm{VC} \%$ & $P Z$ & $\mathrm{VC} \%$ & $P Z$ & $\mathrm{VC} \%$ \\
\hline Rep & 0.084 & 2.3 & 0.064 & 3.0 & 0.076 & 2.0 & 0.088 & 1.6 \\
\hline Prov & 0.032 & 4.7 & 0.003 & 13.8 & 0.004 & 11.2 & 0.004 & 11.4 \\
\hline Rep x Prov & 0.046 & 3.6 & 0.038 & 3.4 & 0.318 & 0.8 & 0.304 & 0.9 \\
\hline Residual & $<0.001$ & 79.4 & $<0.001$ & 73.8 & $<0.001$ & 82.1 & $<0.001$ & 82.4 \\
\hline
\end{tabular}

${ }^{\text {a }}$ Source of variation: Rep = replications, Prov = provenances, Fam $($ Prov $)=$ families nested in provenances, Rep $\times$ Prov $=$ Rep by Prov interaction, Residual $=$ Rep by Fam(Prov) interaction.

b Variables: BD = basic wood density at $1.3 \mathrm{~m}$; Height $=$ tree height; DBHOB and DBHUB = stem diameter at $1.3 \mathrm{~m}$ over bark and under bark, respectively.

${ }^{c} P Z=$ probability of $Z$ to test significance of variance component.

${ }^{\mathrm{d}} \mathrm{VC} \%=$ variance component expressed as a percentage of the total variance.

Table III. Phenotypic and genetic correlations between wood density and growth of Prosopis africana trees evaluated at 13 years in a provenance/progeny test in Niger ${ }^{\mathrm{a}, \mathrm{b}}$.

\begin{tabular}{lccc}
\hline Correlation type & Height & DBHOB & DBHUB \\
\hline Phenotypic & $0.38(<0.001)$ & $0.36(<0.001)$ & $0.34(<0.001)$ \\
Genetic & $0.09(0.36)$ & $0.09(0.41)$ & NE \\
\hline
\end{tabular}

${ }^{\mathrm{a}}$ Height $=$ tree height; DBHOB and DBHUB $=$ stem diameter at $1.3 \mathrm{~m}$ over bark and under bark, respectively; $\mathrm{BD}=$ wood basic density at $1.3 \mathrm{~m}$. $\mathrm{b}$ Value in parenthesis $=$ probability of Pearson $\mathrm{r}$ coefficient $(N=1060$ 1063 trees), and standard error of genetic correlation $(N=1060$ trees, 253 families). $\mathrm{NE}=$ not estimated with DBHUB because variation due to families within provenances was not significant.

may have important practical implications for management of $P$. africana genetic resources in the West African Sahel, but the results and conclusions from this test cannot be extrapolated beyond the sample region in Burkina Faso and Niger. Furthermore, results are based on a single test at one relatively dry site in Niger, and sample sizes were small for provenances and especially for families. The major results are discussed below, followed by a discussion of some practical implications for conservation and tree improvement programs, and suggestions for future research.

\subsection{Variation, clines and correlations in wood density}

Mean wood density of $P$. africana at 13 years in this test $\left(606.3 \mathrm{~kg} / \mathrm{m}^{3}\right)$ was within the range of values observed in other Prosopis species (Goel and Behl, 1995; Cuevas et al., 2008). Wood density was lower than that observed among trees of similar age in a natural stand in Burkina Faso $\left(687 \mathrm{~kg} / \mathrm{m}^{3}\right.$, Nygård and Elving, 2000).

There was significant variation in wood density due to provenances and families within provenances at 13 years. Genetic variation in wood density due to provenances and/or families has also been reported in other tropical hardwood species at relatively young ages (e.g., Arnold et al., 2004; Dvorak et al., 1998; Lauridsen and Kjaer, 2002; Miranda et al.,
2001; Santos et al., 2004; Sotelo Montes et al., 2006; Weber and Sotelo Montes, 2008).

Provenances accounted for relatively greater variation in tree growth than in wood density, based on the variance components. This suggests that environmental differences among provenance locations have produced relatively stronger selection pressures on tree growth (specifically on taproot growth which in turn affects above-ground growth, Weber et al., 2008), than on wood density. This is a hypothesis, however, and there is no direct evidence to confirm that the variation is primarily due to natural selection.

Density and other wood properties of tropical hardwoods typically have higher heritability than growth traits (e.g., Arnold et al., 2004; Raymond, 2002; Sotelo Montes et al., 2006; 2007a; 2007b; 2008; Wei and Borralho, 1997). Results from this test are consistent with this general trend.

Mean wood density of $P$. africana provenances appears to be related to rainfall gradients in the sample region. Provenances from drier parts of the region had denser wood than provenances from more humid parts of the region, when tested at a relatively dry site in Niger. The same clines were observed in tree growth and survival of $P$. africana at 11 years (Weber et al., 2008). To our knowledge, this is the first reported cline in wood density of a hardwood species from the West African Sahel.

The positive correlation between wood density and tree growth, and the cline in wood density may be an adaptive response to bending stress produced by wind in natural stands. In discussing the mechanical design of trees, Mosbrugger (1990) notes that the base of the tree has the highest bending stress and this can be reduced by increasing the strength of supporting tissue at the base of the tree. Strength can be increased by producing denser wood, which has a greater Young's modulus of elasticity. In general, larger trees require greater strength at the base of the stem, compared with smaller trees, in order to reduce the bending stress. This may be particularly important for trees growing in more open stands that are potentially exposed to higher wind velocities. In general, the number of species and trees per unit area (i.e. stand density) are greater in zones with higher rainfall, such as the southern part of the sample region in this study. In these zones, root systems and tree 
crowns of neighboring trees may become interwoven to varying degrees over time, and allow the stand to "collectively" reduce the bending stress produced by wind. This "collective" response to bending stress would be less apparent in zones with lower rainfall and lower stand density, such as the northern part of the sample region in this study. Trees in these zones might require a relatively greater investment in increasing their strength at the base of the tree (i.e. greater wood density) compared with trees in stands that can "collectively" respond to bending stress. This hypothesis requires testing.

\subsection{Practical implications and future research needs}

Assuming that the clines reported in this paper and in an earlier paper (Weber et al., 2008) reflect adaptive variation, and considering the fact that some computer models predict a drier climate in the Sahel during the 21st century (Held et al., 2005), it would be prudent for tree improvement and conservation programs to conserve and collect $P$. africana germplasm from the drier parts of the region for planting in the West African Sahel. Specifically, we recommend that transfers of germplasm should only be made from the drier to the more humid parts of the region.

The phenotypic correlations between tree growth and wood density of $P$. africana were positive but relatively low, and the genetic correlations were not significant in this test. In general, the genetic correlation between growth and density is low for diffuse-porous hardwoods (Zobel and Jett, 1995). This, together with the relatively low heritability for growth traits, suggests that selecting faster-growing trees of $P$. africana at $\sim 13$ y would result in only a modest gain in wood volume and little (if any) gain in wood density in the subsequent generation. This must be considered as a tentative conclusion pending future research, since trait heritability and genetic correlations among traits may change over time, and they also depend on the specific test environment and the genetic population or populations in the test (Zobel and Jett, 1995; Falconner and Mackay, 1996). In this test, phenotypic correlations between density and growth varied among provenances, but genetic correlations were not estimated within provenances due to the small number of families per provenance. If future research demonstrates that genetic correlations also vary among provenances, then greater gains in wood volume and density could be realized by first selecting provenances from the drier parts of the region that have greater growth, wood density and survival, and a stronger genetic correlation between growth and density. Since wood density has a higher heritability than growth traits, this could be followed by selection of families within these provenances based primarily on density, but also considering survival.

Relationships need to be investigated between tree growth, wood density and other wood properties in P. africana. Larger trees tend to have denser wood, and studies of other species demonstrate that denser wood tends to be stronger and stiffer but has greater volumetric shrinkage (e.g., Sotelo Montes et al., 2007a; 2007b). Greater strength and stiffness are desirable for construction purposes, and wood with less shrinkage is generally preferred in order to minimize waste due to poorly oriented boards. Denser wood also tends to have a darker hue (e.g., Sotelo Montes et al., 2008), which is an important aesthetic quality for furniture, walls, floors, carvings, etc.

Multi-location provenance/progeny tests, with larger sample sizes for provenances and families, are needed to investigate genetic variation in wood properties, tree growth and survival of $P$. africana and other important native timber-tree species in the West African Sahel (Weber et al., 2008). The West African Sahel is a transitional ecozone between the relatively humid savannah woodlands and the Sahara Desert, so one would expect clinal variation in tree growth and correlated wood traits in relation to the rainfall gradients in the region. These studies are needed in order to develop appropriate conservation and improvement strategies: this is particularly important for species that are under intensive extraction pressure and whose habitats are disappearing due to climate change.

Acknowledgements: The authors thank the International Fund for Agricultural Development (IFAD) for their generous financial support of the seed collection and trial establishment; Boubé Aw and Hama Moumouni from ICRAF for coordinating the seed collection and trial establishment; Idrissa Habi from ICRISAT for assistance in data collection; I. Maïkano from ICRISAT for preparing a summary of the rainfall data at the ICRISAT Sahelian Centre; Nancy Mandel from the USDA Forest Service for reviewing the statistical methods; and the anonymous reviewers for their useful comments on an earlier version of this manuscript.

\section{REFERENCES}

Arnold R.J., Johnson I.G., and Owen J.V., 2004. Genetic variation in growth, stem straightness and wood properties of Eucalyptus dunnii trials in northern New South Wales. For. Genet. 11: 1-12.

ASTM, 1997. Standard test methods for specific gravity of wood and wood-base materials. ASTM D2395-93. In: Annual book of ASTM Standards 4.10, American society for testing and materials, Philadelphia, pp. 348-355.

Becker W.A., 1984. Manual of quantitative genetics, 4th ed., Academic Enterprises, Pullman, $188 \mathrm{p}$.

Bessega C., Ferreyra L., Julio N., Montoya S., Saidman B., and Vilardi J.C., 2000. Mating system parameters in species of genus Prosopis (Leguminosae). Hereditas 132: 19-27.

Cuevas I.E., Ulloa A.I., Rosende B.R., and Donoso G.J., 2008. Propiedades físicas y mecánicas de la madera de Tamarugo y Algarrobo de la pampa del Tamarugal. Facultad de Ciencias Agrarias, Veterinarias y Forestales, Universidad de Chile. Available online at www.fao.org/DOCREP/006/AD315S/AD315S19.htm

Dvorak W.S., Uruena H., Moreno L.A., and Goforth H., 1998. Provenance and family variation in Sterculia apetala in Colombia. For. Ecol. Manage. 111: 127-135.

Falconer D.S. and Mackay T.F.C., 1996. Introduction to quantitative genetics, Addison Wesley Longman Limited, Edinburgh, 484 p.

Goel V.L. and Behl H.M., 1995. Fuelwood production potential of six Prosopis species on an alkaline soil site. Biomass Bioenergy 8: 17-20.

Held I.M., Delworth T.L., Lu J., Findell K.L., and Knutson T.R., 2005. Simulation of Sahel drought in the 20th and 21st centuries. Proc. Natl. Acad. Sci. USA 102: 17891-17896.

Lauridsen E.B. and Kjaer E.D., 2002. Provenance research in Gmelina arborea Linn. Roxb. A summary of results from three decades of research and a discussion of how to use them. Int. For. Rev. 4: 20-29. 
Miranda I., Almeida M.H., and Pereira H., 2001. Provenance and site variation of wood density in Eucalyptus globulus Labill. at harvest age and its relation to a non-destructive early assessment. For. Ecol. Manage. 149: 235-240.

Mosbrugger V., 1990. The tree habit in land plants, Lecture Notes in Earth Sciences, Springer-Verlag, Berlin, 28 p.

Nygård R. and Elving B., 2000, Stem basic density and bark proportion of 45 woody species in young savanna coppice forests in Burkina Faso. Ann. For. Sci. 57: 143-153.

Panshin A.J. and de Zeeuw C., 1980. Textbook of wood technology, McGraw-Hill Book Company, New York, 722 p.

Pasiecznik N.M., Felker P., Harris P.J.C., Harsh L.N., Cruz G., Tewari J.C., Cadoret K., and Maldonado L.J., 2001. The Prosopis julifloraProsopis pallida complex: A monograph, Henry Doubleday Research Association (HDRA), Coventry, 172 p.

Raymond C.A., 2002. Genetics of Eucalyptus wood properties. Ann. For. Sci. 59: 525-531.

Santos P.E.T., Geraldi I.O., and Garcia J.N., 2004. Estimates of genetic parameters of wood traits for sawn timber production in Eucalyptus grandis. Genet. Mol. Biol. 27: 567-573.

SAS Institute Inc., 2004. SAS/STAT Users' Guide, Version 9.1. SAS Institute Inc., Cary, $5121 \mathrm{p}$.

Sotelo Montes C., Beaulieu J., Hernández R.E., and Weber J.C., 2006. Genetic variation and correlations between growth and wood density of Calycophyllum spruceanum Benth. at an early age in the Peruvian Amazon. Silvae Genet. 55: 217-228.
Sotelo Montes C., Beaulieu J., and Hernández R.E., 2007a. Genetic variation in wood mechanical properties of Calycophyllum spruceanum at an early age in the Peruvian Amazon. Wood Fiber Sci. 39: 578-590.

Sotelo Montes C., Beaulieu J., and Hernández R.E., 2007b. Genetic variation in wood shrinkage, and its correlations with tree growth and wood density of Calycophyllum spruceanum at an early age in the Peruvian Amazon. Can. J. For. Res. 37: 966-976.

Sotelo Montes C., Hernández R.E., Beaulieu J., and Weber J.C., 2008. Genetic variation in wood color and its correlations with tree growth and wood density of Calycophyllum spruceanum at an early age in the Peruvian Amazon. New For. 35: 57-73.

Tybirk K., 1991. Regeneration of woody legumes in Sahel, Aarhus University Press, Aarhus, $81 \mathrm{p}$.

Weber J.C. and Sotelo Montes C., 2008. Variation in tree growth and wood density of Guazuma crinita Mart. in the Peruvian Amazon. New For. 36: 29-52.

Weber J.C., Larwanou M., Abasse T.A., and Kalinganire A., 2008. Growth and survival of Prosopis africana provenances tested in Niger and related to rainfall gradients in the West African Sahel. For. Ecol. Manage. 256: 585-592.

Wei X. and Borralho N.M.G., 1997. Genetic control of wood basic density and bark thickness and their relationships with growth traits of Eucalyptus urophylla in south east China. Silvae Genet. 46: 245-250.

Zobel B.J. and Jett J.B., 1995. Genetics of wood production, SpringerVerlag, Berlin. 


\section{Online Material}




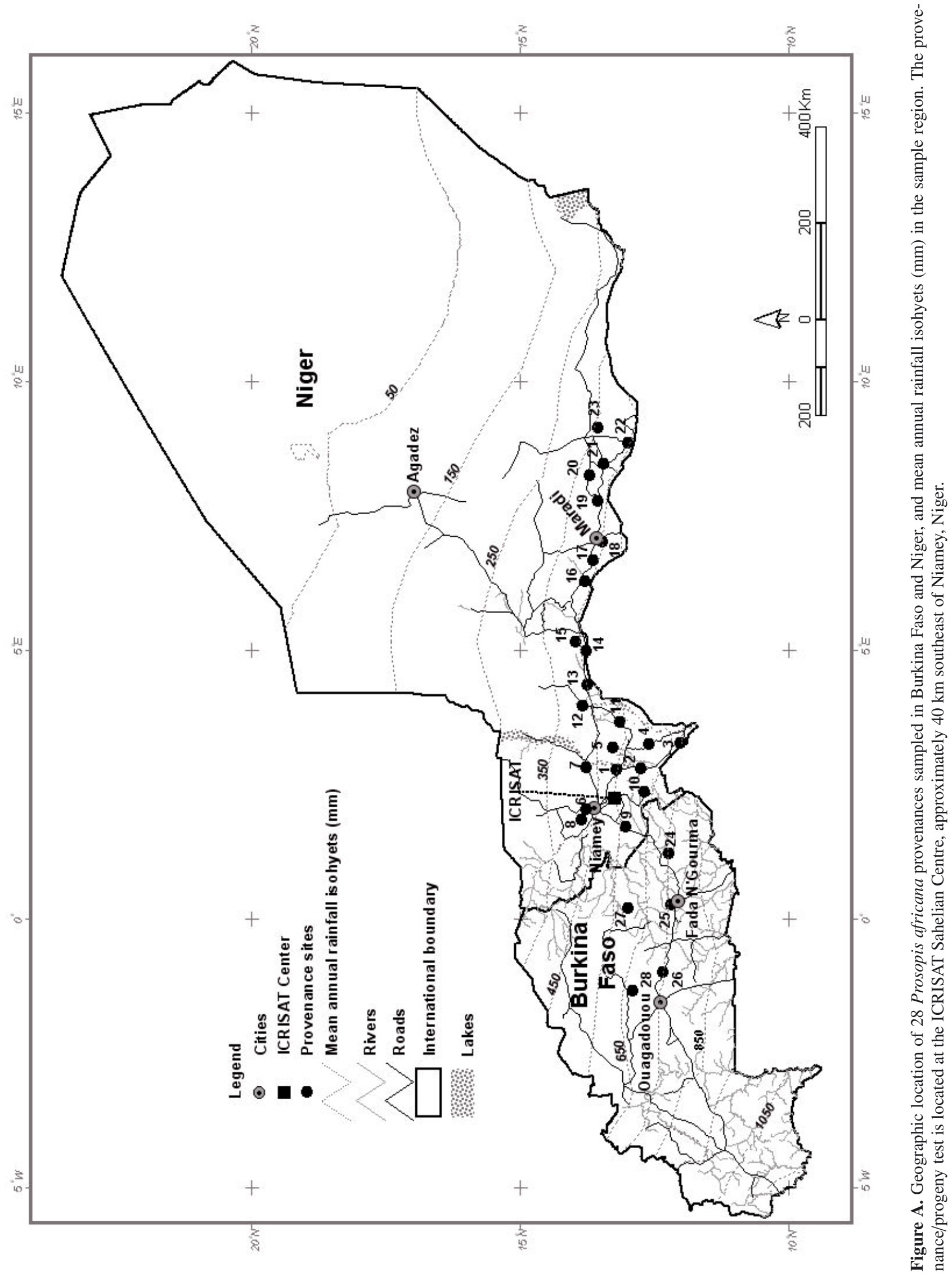


Table A. Mean wood density and growth of Prosopis africana evaluated at 13 years in a provenance/progeny test in Niger. Means are given for all trees and separately for each provenance. Provenances are ordered by longitude, from west to east ${ }^{\mathrm{a}, \mathrm{b}, \mathrm{c}}$.

\begin{tabular}{lccccc}
\hline Code & $\begin{array}{c}\text { BD } \\
\left(\mathrm{kg} / \mathrm{m}^{3}\right)\end{array}$ & $\begin{array}{c}\text { Height } \\
(\mathrm{m})\end{array}$ & $\begin{array}{c}\text { DBHOB } \\
(\mathrm{cm})\end{array}$ & $\begin{array}{c}\text { DBHUB } \\
(\mathrm{cm})\end{array}$ & $N$ \\
\hline All trees & 606.3 & 3.79 & 5.4 & 4.1 & $1062-1078$ \\
28 & 608.3 & 3.18 & 4.2 & 3.2 & $28-31$ \\
26 & 589.7 & 2.87 & 3.7 & 2.7 & $24-28$ \\
27 & 577.9 & 3.09 & 3.9 & 2.8 & 36 \\
24 & 590.7 & 3.11 & 4.1 & 3.1 & $21-23$ \\
9 & 605.3 & 3.55 & 4.6 & 3.5 & $35-36$ \\
6 & 614.9 & 3.97 & 5.8 & 4.5 & 62 \\
10 & 609.7 & 3.73 & 5.1 & 3.9 & $37-39$ \\
1 & 609.3 & 4.13 & 6.5 & 5.0 & 26 \\
2 & 610.4 & 3.87 & 5.4 & 4.2 & 59 \\
7 & 618.0 & 4.24 & 6.4 & 5.0 & 43 \\
5 & 607.3 & 3.95 & 5.6 & 4.3 & 55 \\
4 & 609.4 & 4.01 & 5.7 & 4.4 & 60 \\
3 & 598.2 & 3.45 & 4.6 & 3.5 & 37 \\
11 & 596.9 & 3.83 & 5.2 & 4.0 & 64 \\
12 & 610.1 & 4.07 & 6.1 & 4.6 & 66 \\
13 & 632.4 & 3.96 & 5.7 & 4.4 & 30 \\
15 & 612.7 & 3.61 & 5.1 & 3.9 & 27 \\
17 & 622.8 & 4.08 & 5.8 & 4.4 & 36 \\
18 & 606.5 & 3.81 & 5.5 & 4.3 & $49-50$ \\
19 & 598.0 & 3.92 & 5.8 & 4.5 & $52-53$ \\
20 & 620.8 & 4.03 & 5.9 & 4.5 & $61-62$ \\
21 & 605.2 & 3.86 & 5.5 & 4.3 & 49 \\
22 & 586.4 & 3.62 & 5.4 & 4.1 & $50-51$ \\
23 & 601.3 & 3.69 & 5.1 & 3.9 & $54-55$ \\
\hline
\end{tabular}

a Provenances 1-23 from Niger and 24-28 from Burkina Faso. Four provenances in Figure $1(8,14,16$ and 25$)$ not analyzed due to small sample size $(<20$ trees).

b Variables: $\mathrm{BD}=$ basic wood density at $1.3 \mathrm{~m}$; Height $=$ tree height; DBHOB and DBHUB $=$ stem diameter at $1.3 \mathrm{~m}$ over bark and under bark, respectively.

${ }^{c}$ Standard deviations among all trees: $\mathrm{BD}=40.0 \mathrm{~kg} / \mathrm{m}^{3}$, Height $=0.85 \mathrm{~m}$, $\mathrm{DBHOB}=1.9 \mathrm{~cm}, \mathrm{DBHUB}=1.6 \mathrm{~cm}$. 